\title{
PURCHASE DECISION BASED ON THE BRAND IMAGE, PRODUCT DESIGN AND LIFESTYLE ON CONVERSE SHOES IN SURAKARTA
}

\author{
Assa Agustin, Sudarwati, Siti Maryam \\ Program Studi Manajemen, Fakultas Ekonomi, Universitas Islam Batik Surakarta \\ JL. H Agus Salim No 10 Telp (0271) 740160 Surakarta 57174 \\ E-mail: assaagustin618@gmail.com
}

\begin{abstract}
The purpose of this study was to determine the effect of brand image, product design and lifestyle on purchasing decisions for Converse shoes in Surakarta. This type of research uses quantitative descriptive research. The variables in this study were a brand image, product design and lifestyle. The population of this study was all people of Surakarta City, especially those who wear Converse shoes. The research sample consisted of 100 people, using purposive sampling technique, and data collection using a questionnaire. The data analysis technique used in this research is the coefficient of determination analysis technique, the classical assumption test and multiple linear regression. The test results of multiple linear regression analysis show that brand image has no significant effect on purchasing decisions, product design has a significant effect on purchasing decisions, and lifestyle has a significant effect on purchasing decisions.
\end{abstract}

\section{Keywords: Brand Image, Product Design, Lifestyle}

\section{Introduction}

The development of an increasingly advanced shoe era is not only a clothing tool but also a factor in the field of fashion in society. The development of increasingly sophisticated and advanced technology requires businesses to follow and master the development of existing technology, in marketing, consumers are people who need a purchase decision is in the consumer. This makes shoe manufacturers see the needs of consumers so that there are opportunities to create a product. Understanding consumer behavior is also important for merchants because every consumer has a certain reason to choose a product, if the consumer has no experience in using the product then they will trust a popular or well-known brand. It is for this reason that companies are encouraged to strengthen their brand position to build a positive brand image, and stay firmly in the minds of consumers because through the brand image, consumers can identify products, evaluate quality, reduce purchase risk and gain experience. and satisfaction of these product differences. 
Vol-5, Issue-1, 2021 (IJEBAR)

E-ISSN: 2614-1280 P-ISSN 2622-4771

http://jurnal.stie-aas.ac.id/index.php/IJEBAR

Sneakers are one of the growing industries. Purchasing decisions are important to note because it is certainly a consideration of how the company will carry out its marketing strategy in the future. Efforts to support the company's success in influencing consumer purchasing decisions by building communication channels with consumers, building brands for consumers through marketing strategies, and innovation of new differences in products.

One product that always follows consumer tastes is shoes. Some shoes never change models, but still in demand by consumers. Shoes are sports shoes made of thick rubber soles and simple straps. Converse is a brand that specializes in the manufacture of such sports shoes. Based on the Best Sneaker Brands survey (2017), respondents chose to determine the ten best footwear brands in the world. The result is that Converse occupies the third tier that Converse has a good brand image in the eyes of consumers and can maintain a leading position even if it does not occupy the first place. Where Converse portrays itself as a quality shoe and suitable for all circles, the design used by Converse also has a distinctive logo of the star in each shoe, the logo indicates that the star logo is definitely that the brand is the Converse brand.

Product design is the process of creating products that combine functional and aesthetic elements to be useful and add value to society. Nowadays, the value of a product is not only a priority of benefits but also shows the aesthetic value of the product design. Besides, consumers who still attach importance to lifestyle will consider buying the brand of the product. Interact with the environment.

Some previous research behind this research include Fahrul Ulum(2000) conducted a study with the title Influence of Brand Image Product Quality And Product Design on Converse Shoe Purchasing Decisions (Case Study On Feb Unisma Students) stated that brand image, product quality, and product design have a positive and significant effect on purchasing decisions, Syafrida Hafni (2016) with the title of lifestyle influence, halal label and price on the decision to purchase cosmetics wardah on students of the management study program of the faculty of economics medan area stated Lifestyle has a positive and significant effect on the decision to purchase Wardah Cosmetics to students of the Management Study Program of the Faculty of Economics, University of Medan Area.

\section{Literature Review}

\section{Purchasing Decisions}

Purchasing decisions are the activities of individuals directly involved in the decision making to make purchases of products offered by the seller. Decision making is an individual activity directly involved in obtaining and using the goods offered by Kotler (2011: 184). 
Vol-5, Issue-1, 2021 (IJEBAR)

E-ISSN: 2614-1280 P-ISSN 2622-4771

http://jurnal.stie-aas.ac.id/index.php/IJEBAR

\section{Brand image}

Brand image is how consumers present the brand in real time which is an opinion formed by consumers as an achievement of all that the Company's Brand image does to be one of the things that consumers care about in making purchases Ismail (2012:62).

\section{Product Design}

Product design is the process of designing the shape and benefits of the product so that it can have a distinctive feature. the design simply describes the outer shape of the product. An interesting product form is a description of Azany's quality design (2014:45).

\section{Lifestyle}

Suggesting the sense of lifestyle is the lifestyle of a person who is expressed in his activities, interests and opinions. Lifestyle encourages individual needs and attitudes and influences the activity and use of products. Kotler and keller (2012).

\section{Research Method}

This research uses a quantitative method using an associative descriptive design. Quantitative research is experimental research and survey data on this research in the form of figures and analysis using statistics. In this study, the sampling technique used was Purposive Sampling which is 100 respondents who use Converse shoes in Surakarta.

\section{Results And Discussions}

Data Analysis

1) Multiple Linier Regresion

Table 1 Multiple Linier Regresion

\begin{tabular}{lcc}
\hline \multicolumn{1}{c}{ MODEL } & \multicolumn{2}{c}{ Unstandardized Coefficients } \\
& $B$ & Std. Error \\
\hline Constant & $-1,675$ & 2,020 \\
Brand Image & 0,161 & 0,095 \\
Product Design & 0,481 & 0,094 \\
Lifestyle & 0,421 & 0,087 \\
\hline
\end{tabular}

Source : primary data processed

Based on multiple linear regression tests obtained mathematical models as follows:

$$
Y=-1,675+0,161 X_{1}+0,481 X_{2}+0,087 X_{3}+e \ldots \ldots \ldots \ldots . .(1)
$$


Vol-5, Issue-1, 2021 (IJEBAR)

E-ISSN: 2614-1280 P-ISSN 2622-4771

http://jurnal.stie-aas.ac.id/index.php/IJEBAR

Descriptions :

$\mathrm{X}_{1} \quad$ : Brand Image

$\mathrm{X}_{2} \quad$ : Product Design

$\mathrm{X}_{3} \quad$ : Lifestyle

2) R-Square Test

Table 2. R-Square Test

\begin{tabular}{cccc}
\hline Model & R & R-Square & Adjusted R-Square \\
\hline & 0,761 & 0,579 & 0,566
\end{tabular}

Source : primary data processed

Based on the results of the analysis above obtained $\mathrm{R}$ square value of 0.579 or $57.9 \%$. This means that the variable ratio of brand image, product design, and lifestyle is $57.9 \%$, while the remaining $42.1 \%$ is influenced by other variables as price, product quality, and others.

3) F- Test

Table 3. F- Test

\begin{tabular}{cccc}
\hline Model & F-Table & Sig & Descriptions \\
\hline $\begin{array}{c}\text { Regression } \\
\text { residual }\end{array}$ & 44,086 & 0,000 & $\mathrm{H}_{\mathrm{O}}$ Rejected \\
\hline
\end{tabular}

\section{Source : primary data processed}

Based on the results of F-test analysis using SPSS program obtained F-Score results of 48,086 $>$ F-table 2.70 and significant $0.000<0.05$ then Ho was rejected and Ha received means there is a brand image influence, product design and lifestyle simultaneously to the decision to purchase Converse shoes in Surakarta.

4) T-Test

Table 4. T-Test

\begin{tabular}{lcccc}
\hline \multicolumn{1}{c}{ Model } & $\mathbf{T}_{\text {Score }}$ & $\mathbf{T}_{\text {table }}$ & Sig & Descriptions \\
\hline Brand Image & 1,694 & 1,988 & 0,093 & Ho accepted \\
Product Design & 5,138 & 1,988 & 0,000 & $\mathrm{H}_{\mathrm{O}}$ Rejected \\
Lifestyle & 4,829 & 1,988 & 0,000 & $\mathrm{H}_{\mathrm{O}}$ Rejected
\end{tabular}


Vol-5, Issue-1, 2021 (IJEBAR)

E-ISSN: 2614-1280 P-ISSN 2622-4771

http://jurnal.stie-aas.ac.id/index.php/IJEBAR

Based on the results of the above t-test can be concluded that:

a. Variable Brand image (X1) Based on the calculation above obtained the results of $>\mathrm{t}$-score 1,694 and significant value of $0.093>0.05$, then Ho accepted so that the brand image variable partially does not have a positive and significant effect on the purchase decision on Converse shoes in Surakarta.

b. Product Design Variables (X2) Based on the calculation above obtained $<\mathrm{t}$-score 5,138 and a significant value of $0.000<0.05$, then Ho rejected so that product design variables partially have a positive and significant effect on the purchasing decision on Converse shoes in Surakarta.

c. Lifestyle Variables (X3) Based on the calculation above obtained the results of < t-score 4,829 and a significant value of $0.000<0.05$, then Ho rejected so that lifestyle variables partially have a positive and significant effect on the purchase decision on Converse shoes in Surakarta.

\section{Discussions}

1) Variable Brand image (X1) has no effect on purchasing decisions on Converse shoes in Surakarta

This can be seen from t-score results of 1,694 smaller than the t-table with a significant value of 0.093 greater than 0.05 , then Ho accepted it can be concluded that the brand image variable partially does not have a positive and significant effect on the decision to purchase converse shoes in Surakarta, and has a positive coefficient value of 0.161 meaning that the brand image is less supportive then the decision to purchase Converse shoes in Surakarta decreased.

Brand image or brand image that is the image or impression caused by a brand in the mind of the customer, not all customers have the same picture or impression of a product sometimes they only know the brand but do not understand the impression given by the brand, with the brand image is lacking and unable to give a good impression of the possibility of consumers are a little hesitant to make a purchase. Based on the description above, it can be concluded that brand image research has not proven to be a factor that influences the purchasing decision on Converse shoes in Surakarta.

\section{2) Product Design Variables (X2) affect the purchasing decision on Converse shoes in Surakarta}

This can be seen from thitung of 5,138 with a significant level of 0.000 and has a positive value of regression coefficient of 0.481 meaning that if the product design increases, then the decision to purchase converse shoes in Surakarta has increases. Product design is the form and benefit of the product so that it can have a distinctive feature.

This is proven by most consumers who prefer product design ranging from shape, color to model because if the product design provided usually attracts consumers, it will make purchasing decisions and recommend to others. Based on the description above, it can be concluded that 
Vol-5, Issue-1, 2021 (IJEBAR)

E-ISSN: 2614-1280 P-ISSN 2622-4771

http://jurnal.stie-aas.ac.id/index.php/IJEBAR

product design research proved to be a factor that influenced the purchasing decision on Converse shoes in Surakarta.

\section{3) Lifestyle Variables (X3) affect purchasing decisions on Converse shoes in Surakarta}

This is evidenced from t-score of 4,829 greater than t-table and has a signification rate of 0.000 less than the limit of 0.05 by having a positive value of regression coefficient of 0.421 which means that a lifestyle owned by high consumers will increase the purchasing decision on Converse shoes in Surakarta.

Consumer behavior to adjust to social conditions in meeting the need to integrate with their environment, with a high lifestyle is able to show the wearer's self-image or pride in using the product will make a purchase decision on Converse shoes in Surakarta. Based on the description above, it can be concluded that this lifestyle research proved to be a factor that influenced the purchasing decision on Converse shoes in Surakarta.

\section{Conclusion}

1) In this study shows there is a simultaneous and significant influence between variable brand image, product design and lifestyle on purchasing decisions on Converse shoes in Surakarta.

2) Brand image (X1) partially has no positive and significant effect on the purchasing decision on Converse shoes in Surakarta.

3) Product design (X2) partially affects the positive and significant purchasing decision on Converse shoes in Surakarta.

4) Lifestyle (X3) has a positive and significant effect on the purchasing decision on Converse shoes in Surakarta.

\section{References}

Adiwidjaja, A. J. (2017). Pengaruh Brand Image dan Brand Trust Terhadap Keputusan Pembelian Sepatu Converse . Manajemen Bsnis 5(2), http://publication.petra.ac.id/6063.

Alsabiyah, T., Hidayat, K., \& Fanani, D. (2019). Pengaruh Gaya Hidup Terhadap Keputusan Pembelian (Survei pada mahasiswa/mahasiswi Universitas brawijaya yang menggunakan sepatu sneakers merek converse). Jurnal Administrasi Bisnis, 70(1).

Amanah, D. (2011). Pengaruh Promosi Dan Brand Image (Citra Produk) Terhadap Loyalitas Pembelian Produk Pepsodent Di Ramayana Plaza Jalan Aksara Medan . Jurnal Keuangan \& Bisnis, 221-233. 
Ariella, I. R. (2018). Pengaruh Kualitas Produk, Harga Produk dan Desain Produk terhadap Keputusan Pembelian Konsumen Mazelnid. performa. Jurnal Manajemen dan Start-Up Bisnis, 3(2).

Dopo, E. R. (2020). PENGARUH PROMOSI, DESAIN PRODUK DAN KUALITAS PRODUK TERHADAP KEPUTUSAN PEMBELIAN SEPATU ALL STAR DI KALANGAN MAHASISWA DI SURABAYA TIMUR (Studi Kasus Pada Mahasiswa Untag, Unitomo dan Perbanas) . Doctoral dissertation, universitas 17 A, http://repository.untagsby.ac.id/id/eprint/5679.

Ghozali, I. (2013). Aplikasi Analisis Multivariate dengan Program IBM SPSS 23 . Semarang: Universitas Diponegoro.

Herawati, H., Prajanti, S. D. W., \& Kardoyo, K. (2019). Predicted Purchasing Decisions from Lifestyle, Product Quality and Price Through Purchase Motivation. Journal of Economic Education, 8(1), 1-11.

Kartika, R. P. (2019). Pengaruh Brand Image, Gaya Hidup, Dan Lokasi Terhadap Keputusan Pembelian Café Tiga Tjeret Di Surakarta. Jurnal Ilmiah Edunomika, 3(01). 